\title{
Microbiological Safety and the Management of Microbial Resources in Artisanal Foods and Beverages: The Need for a Transdisciplinary Assessment to Conciliate Actual Trends and Risks Avoidance
}

\author{
Vittorio Capozzi ${ }^{1, * \mathbb{D}}$, Mariagiovanna Fragasso ${ }^{2}$ and Pasquale Russo ${ }^{2}$ \\ 1 Institute of Sciences of Food Production, National Research Council (CNR), c/o CS-DAT, \\ Via Michele Protano, 71121 Foggia, Italy \\ 2 Department of the Sciences of Agriculture, Food and Environment, University of Foggia, Via Napoli 25, \\ 71122 Foggia, Italy; mariagiovanna.fragasso@gmail.com (M.F.); pasquale.russo@unifg.it (P.R.) \\ * Correspondence: vittorio.capozzi@ispa.cnr.it; Tel.: +39-(0)881-630-201
}

Received: 27 January 2020; Accepted: 19 February 2020; Published: 22 February 2020

check for updates

\begin{abstract}
Current social and environmental trends explain the rising popularity of artisanal fermented foods and beverages. In contrast with their marketing success, several studies underline a lack of regulations necessary to claim differences occurred from the farm to the fork and to certify high quality and safety standards. Microbial-based fermentative processes represent the crucial phase in the production of fermented foods and beverages. Nevertheless, what are the effects of the application of the "artisanal" category to the management of food fermentations? This opinion paper is built up on this issue by analyzing microbial aspects, instances of innovation, safety issues, and possible solutions. Evidence indicates: (i) a global curiosity to exploit food fermentations as drivers of innovation in artisanal contexts and (ii) an increasing interest of the artisanal producers into management of fermentation that relies on native microbial consortia. Unfortunately, this kind of revamp of "artisanal food microbiology," rather than re-establishing artisanal content, can restore the scarce hygienic conditions that characterized underdeveloped food systems. We highlight that in the scientific literature, it is possible to underline existing approaches that, surpassing the dichotomy between relying on spontaneous fermentation and the use of commercial starter cultures, depict a "third way" to conjugate interest in enhancing the artisanal attributes with the need for correct management of microbial-related risks in the final products.
\end{abstract}

Keywords: artisanal fermented food; fermentation; artisanal fermented beverage; safety; risks; spontaneous fermentation; starter cultures; spoilage microbes; pathogens; toxins

\section{Introduction}

Fermentation of edible matrices has been a precious form of food preservation and functional/nutritional enhancement for millennia [1]. The fermentation of edible matrices is the microbial-based process mainly characterized by the conversion of sugars into alcohols and acids, always associated with a subset of secondary microbial-based modifications. On the whole, this so-called "oldest biotechnology" modifies the original matrices into a new food product (e.g., kefir, beer, kombucha, sauerkraut, cheese, miso, kimchi, tempeh, natto, sourdough bread) [2]. In fact, fermented foods or beverages are "produced through controlled microbial growth, and the conversion of food components through enzymatic action" [1]. The fact that this ancient form of preservation was present in human societies worldwide well explains the variety and the diversity of existing fermented foods 
and beverages [3]. Before the advent of modern microbiology, food fermentations (unconsciously) relied on naturally occurring microorganisms [4]. For example, in the field of sourdough technology by applying the back-slopping, in other terms, "the inoculation of the raw material with a small amount of dough from a previous successful fermentation" [5], while in other production sectors, the practice found different declinations, named, for example, "inoculum enrichment" (general), "sieroinnesto" (cheese sector), or "pied de cuve" (wine sector) [6]. With the development of tailored microbiological techniques and the rise of industrial food production, to ensure the standardization of consistency, safety, and quality of the final fermented products the scientific community developed the technology of starter cultures: "a microbial preparation of large numbers of cells of at least one microorganism to be added to a raw material to produce a fermented food by accelerating and steering its fermentation process" [7]. As more recently defined, "commercial starter cultures are standardized inoculum to be used for the production of fermented foods. Starter cultures are produced by specialized manufacturers. Rigorous quality assurance and quality control are conducted to ensure the performance, composition, and safety of the culture" [8].

\section{Globally Fermented Foods and Beverages and the Microbial Diversity Associated with}

With a few exceptions (e.g., [9]), all globally fermented foods and beverages are based on ancient artisanal/typical/traditional productions [10]. In order to provide an overview of micro-biodiversity associated to the different edible matrices subjected to the fermentative process, we refer to the nine categories proposed by Tamang et al. [3] that differentiated global products in: i) fermented cereals; ii) fermented vegetables and bamboo shoots; iii) fermented legumes; iv) fermented roots/tubers; v) fermented milk products; vi) fermented and preserved meat products; vii) fermented, dried, and smoked fish products; viii) miscellaneous fermented products; and ix) alcoholic fermented beverages. In Table 1, you can find a list of some of the genera/species of prokaryotic and eukaryotic microorganisms found in association with the fermentative processes in the corresponding categories.

Table 1. A list of microorganisms involved in the fermentative processes of the main categories of globally fermented foods with examples of microorganisms involved in the corresponding fermentative processes. Information reported in accordance to Tamang et al. [3], with integrations from other studies $[11,12]$.

\begin{tabular}{|c|c|}
\hline $\begin{array}{l}\text { Major Groups of Globally } \\
\text { Fermented Foods }\end{array}$ & Microorganisms Involved in the Fermentation Process \\
\hline Fermented cereals & $\begin{array}{l}\text { Lactococcus sp., Leuc. mesenteroides, Lb. delbrueckii, Lb. fermenti, Lb. coryniformis, } \\
\text { Leuconostoc sp., Ped. acidilactis, Ped. cerevisae, Streptococcus sp., Ent. faecalis, Ent. cloacae, } \\
\text { Weissela sp., Bacillus amyloliquefaciens, Klebsiella pneumoniae, Aerobacter sp., Candida } \\
\text { cacaoi, Cand. fragicola, Cand. glabrata, Cand. kefyr, Cand. pseudotropicalis, Cand. sake, Cand. } \\
\text { tropicalis, Debaryomyces hansenii, Deb. tamarii, Issatchenkia terricola, Kluyveromyces } \\
\text { marxianus, Sacch. cerevisiae, Torulopsis candida, Tor. holmii, Monascus purpureus, Rhizopus } \\
\text { sp., Cephalosporium sp., Mucor sp., Fusarium sp., Penicillum sp., Aspergillus sp., } \\
\text { Endomycopsis sp., Hansenula sp. }\end{array}$ \\
\hline $\begin{array}{l}\text { Fermented vegetables and bamboo } \\
\text { shoots }\end{array}$ & $\begin{array}{l}\text { Leuc. mesenteroides, Leuc. citreum, Leuc. gasicomitatum, Leuc. fallax, Leuc. kimchii, Leuc. } \\
\text { inhae, W. koreensis, W. kimchii, W. cibaria, Lb. plantarum, Lb. sakei, Lb. delbrueckii, Lb. } \\
\text { buchneri, Lb. brevis, Lb. fermentum, Ped. acidilactici, Ped. pentosaceus, Lc. lactis, Ent. } \\
\text { durans, Tetragenococcus halophilus, Bacillus subtilis, B. lichniformis, B. coagulans, B. cereus, } \\
\text { B. circulans, B. firmus, B. pumilus, B. sphaericus Candida sp., Halococcus sp., Haloterrigena } \\
\text { sp., Kluyveromyces sp., Lodderomyces sp., Natrialba sp., Natronococcus sp., Pichia sp., } \\
\text { Saccharomyces sp., Sporisorium sp., Trichosporon sp., Pseudomonas sp., Halorubrum } \\
\text { orientalis, Halosarcina pallid, Sphingobium sp., Thalassomonas agarivorans }\end{array}$ \\
\hline Fermented legumes & $\begin{array}{l}\text { Bacillus subtilis, B. brevis, B. circulans, B. coagulans, B. licheniformis, B. pumilus, B. } \\
\text { sphaericus, Lysinibacillus fusiformis Rhiz. oligisporus, Rhiz. arrhizus, Rhiz. oryzae, Rhiz. } \\
\text { stolonifer, Asp. niger, Citrobacter freundii, Enterobacter cloacae, K. pneumoniae, K. } \\
\text { pneumoniae subsp. ozaenae, Pseudomas fluorescens, Lb. fermentum, Lb. lactis, Lb. plantarum, } \\
\text { Lb. reuteri, Pantoea agglomerans, P. gaananatis, Enterococcus sp., Pseudomonas sp., } \\
\text { Rhodococcus sp., Asp. oryzae, Asp. flavus, Asp. fumigatus, Asp. niger, Asp. retricus, Asp. } \\
\text { spinosa, Asp. terreus, Asp. wentii, Botrytis cineara, Ped. halophilus, Staphylococcus sp. }\end{array}$ \\
\hline
\end{tabular}


Table 1. Cont.

\begin{tabular}{|c|c|}
\hline $\begin{array}{l}\text { Major Groups of Globally } \\
\text { Fermented Foods }\end{array}$ & Microorganisms Involved in the Fermentation Process \\
\hline Fermented roots/tubers & $\begin{array}{l}\text { Bacillus sp., Lb. plantarum, Leuc. mesenteroides, Lb. cellobiosus, Lb. brevis; Lb. coprophilus, } \\
\text { Lc. lactis; Leuc. lactis, Lb. bulgaricus, Klebsiella sp., Leuconostoc sp., Corynebacterium sp., } \\
\text { Candida sp., Micrococcus sp., Pseudomonas sp., Acinetobacter sp., Moraxella sp., } \\
\text { Rhizopus sp. }\end{array}$ \\
\hline Fermented milk products & $\begin{array}{l}\text { Lc. lactis subsp. cremoris, Lc. lactis subsp. lactis, Lb. alimentarius, Lb. biofermentans, Lb. } \\
\text { brevis, Lb. delbrueckii subsp. delbrueckii, Lb. delbrueckii subsp. lactis, Lb. farciminis, Lb. } \\
\text { helveticus, Lb. casei, Lb. plantarum, Lb. salivarius, Leuconostoc spp., Strep. thermophilus, } \\
\text { Ent. durans, Ent.faecalis, Ent. faecium, Ped. pentosaceous, Ped. acidilactici, Bifidobacterium } \\
\text { spp., Staphylococcus spp., Brevibacterium linens, Propionibacterium freudenreichii, Weissella } \\
\text { confusa, Candida sp., Saccharomycopsis sp., Debaryomyces hansenii, Geotrichum candidum, } \\
\text { Penicillium camemberti, P. roqueforti, Pichia kudriavzevii }\end{array}$ \\
\hline $\begin{array}{l}\text { Fermented and preserved meat } \\
\text { products }\end{array}$ & $\begin{array}{l}\text { Lb. pentosus, Lb. plantarum, Lb. brevis, Lb. paracasei, Lb. fermentum, Lb. acidipiscis, Lb. } \\
\text { farciminis, Lb. rossiae, Lb. fuchuensis, Lb. namurensis, Lc. lactis, Lb. sakei, Leuc. citreum, } \\
\text { Leuc. fallax, Ped. acidilactici, Ped. pentosaceus, Ped. stilesii, W. cibaria, W. paramesenteroides, } \\
\text { Ent. faecalis, Ent. faecium, Ent. hirae, Bacillus subtilis, B. mycoides, B. thuringiensis, } \\
\text { Staphylococcus spp., Micrococcus sp. }\end{array}$ \\
\hline $\begin{array}{l}\text { Fermented, dried, and smoked fish } \\
\text { products }\end{array}$ & $\begin{array}{l}\text { Lc. lactis, Lb. plantarum, Lb. pobuzihii, Lb. fructosus, Lb. amylophilus, Lb. coryniformis, Ent. } \\
\text { faecium, Ent. faecalis, Bacillus subtilis, B. pumilus, B indicus, Micrococcus sp., Staphylococcus } \\
\text { cohnii subsp. cohnii, S. carnosus, Strep. faecalis, Sarcina sp., Corynebacterium sp., } \\
\text { Tetragenococcus halophilus subsp. flandriensis, Pseudomonas sp., Halococcus sp., } \\
\text { Halobacterium salinarium, H. cutirubrum, Clostridium irregular, Azorhizobium caulinodans, } \\
\text { Candida sp., Saccharomycopsis sp. }\end{array}$ \\
\hline Miscellaneous fermented products & $\begin{array}{l}\text { Acetobacter aceti subsp. aceti, Acetobacter pasteurianus, Acetobacter polyxygenes, Acetobacter } \\
\text { xylinum, Acetobacter malorum, Acetobacter pomorum, Candida lactis-condensi, Candida } \\
\text { stellata, Hanseniaspora valbyensis, Hanseniaspora osmophila, Saccharomycodes ludwigii, Sacch. } \\
\text { cerevisiae, Zygosaccharomyces bailii, Zygosaccharomyces bisporus, Zygosaccharomyces lentus, } \\
\text { Zygosaccharomyces mellis, Zygosaccharomyces Pseudorouxii, Zygosaccharomyces rouxii }\end{array}$ \\
\hline
\end{tabular}

The objective of this list is to provide a brief representation of the dimension of the microbial diversity we deal with in the management of the heterogeneous class of globally fermented foods and beverages. An issue that represents the "living matter" is the basis of the subject of this opinion paper.

\section{Artisanal Foods and Similar Categories: The Borders and Overlapping Concept}

Different terms can be used to describe the degree of originality of a given production: territorially, tipicity, traditionality, communality, and artisanality. They represent a sort of grey scale so blended that we can often confuse them. "Territoriality" measures "the degree of physical connection between a food product and its place of origin," including the different phases associated with the productive chain, comprising also distribution and final consumption [13]. "Typicity" describes "the physical aspects that distinguish the production process and the final product in as far as they are unique or logically linked to the place of origin" [13]. "Traditionality" measures the originality in terms of "time" since "first appeared in the place of origin." [13]. "Communality" identifies "the sharing of experience (know-how as well as social) [ ... ] by the supply chain actors," thus quantifying "the degree of horizontal and vertical collaboration among these actors" [13]. "Artisanality" describes processed products "that are made and sold by individual small-scale non-agricultural food producers (bakers, butchers, brewers, etc.) and named after the place (area or town) where the producers are located" [13]. In addition, in order to consider this little glossary exhaustive, we have to include a wording recognized by international intellectual property law, "Geographical Indications" (GIs), whose significance is connected to trademarks. In fact, "Geographical Indication is a sign used on 
goods that have a specific geographical origin and possess qualities, reputation or characteristics that are essentially attributable to that place of origin" [14].

It appears clear that while the words "territorially," "tipicity," and "traditionality" describe/measure different aspects of the connection with a given place of origin, "communality" and "artisanality" are more related to a way to produce, and hence can partially overlap with the previous concepts (i.e., territorially, tipicity, and traditionality). Moreover, we have to underline that, even if artisanal products have become more and more popular in recent years (a popularity also addressable to the increasing interest in social and environmental issues considered linked to artisanal foods), there are a lack of regulations/standards necessary to claim/certify differences occurred in pre-production, production, and post-production that can be of help in recognized artisanal products (particularly differentiating them from the commercial ones) [15]. Taken together, these observations indicate how vague the use of the term artisanal can be and how wide the discretionary margins of the producers remain [15].

\section{The "Artisanal" Concept Extended to Food Fermentations: Existing Instances of the Stakeholders}

The fact that "artisanality" is deeply related to a way to produce foods fosters the idea that all the phases of production can be "handcrafted," and hence at an individual/small-scale level. Probably, the fermentative process can be considered the crucial phase in the production of fermented foods and beverages. What are the effects of the application of the "artisanal" category to the management of food fermentations? An issue difficult to cope with by reason of the atomistic nature of the artisanal markets of fermented products. However, it is possible to intercept some echoes from the "real world." In other terms, it is possible to underline some authoritative "voices" susceptible to be considered representative of the existing instances of the stakeholders. Here, we selected two examples in order to testify on the actual trends. An interesting point of view arises listening to Piero Sardo, president of the Slow Food Foundation for Biodiversity Onlus: "With industrial starters, cheese made in the mountains will be only slightly different from cheese made in the plains. [ ... ] With the industrial packets, the music is already written and the cheesemaker just plays it" [6]. Hence, one of the more important proponents of Slow Food, an association that builds an international movement around the valorization of artisanally produced foods [16], claimed the importance of avoiding the use of starter cultures in order to restore the artisanal "fermentative" practices. The second example, in the field of gastronomic sciences, deals with a recent "debate" in the journal Nature Microbiology on the topic of "artisanal food microbiology" $[17,18]$. On the one side, the young scientist Arielle Johnson, in a "feature paper," underlines the relevance of microbial resources as a "culinary tool" to allow "both professional and amateur cooks to create entirely new flavours from existing ingredients" [17]. In other terms, she proposed microorganisms as creative agents in the hands of food-makers and of gastronomic actors. On the other side, Cocolin et al. [18], referring to Johnson's argumentation, addressed a published letter to the editor of the journal highlighting the interest in the subject, but overall stressing how crucial it can be to "take into adequate consideration the risks of fermenting in non-specialized facilities, such as restaurant kitchens."

On the whole, these two examples warn about relevant trends in the field of the management of food fermentations at the artisanal level: the renovated interest of artisanal producers into spontaneous fermentation (including "inoculum enrichment" managements that rely on native microbial consortia) and the global interest to exploit food fermentations as drivers of innovation in artisanal contexts. In addition, we have to always remember that "much smallscale fermentation in developing countries is still conducted" exploiting spontaneous microbial consortia [19].

\section{5. "Artisanal Fermentation" and the Safety Issues: Concrete Microbial-Related Risks}

Here, we propose an overview of the concrete chemical and biological risks associated with microorganisms and to their metabolic products in the context of spontaneous fermentations (a category that includes, as said, inoculum enrichment managements based on indigenous microbial 
consortia) [20], a way to remember and underline how certain "artisanal fermentations" can pose serious hazards to human health. On the one side, there are the biological contaminants, in other words, the microbial foodborne pathogens found in association with principal categories of fermented foods and beverages (e.g., wine, fermented cereals, cheese, sausages, fermented fish). On the other side, there are the chemical contaminants that are toxic by-products of microbial origin. Pathogenic microbes include Bacillus cereus, Escherichia coli, Salmonella sp., Escherichia coli O157:H7, Listeria monocytogenes, Aeromonas, Klebsiella, Campylobacter, and Shigella sp. and undesirable microbes like Bacillus cereus, Proteus mirabilis, Staphylococcus aureus, Proteus penneri, Enterococcus faecalis, and Staphylococcus saprophyticus [21-23]. In particular, fermented products based on animal matrices are extremely vulnerable to contamination [21,24]. Chemical contaminants include several classes of microbial-related molecules including mycotoxins (e.g., aflatoxins, deoxynivalenol, fumonisins, nivalenol, ochratoxin, zearalenone), biogenic amines (cadaverine, histamine, isoamylamine, phenylethylamine, putrescine, and tyramine), ethyl carbamate, and cyanogenic glycosides $[21,25,26]$. Coming back to microbial-associated hazards for human health, it is essential to separate (i) risks associated with microbial genera/species always undesired in association with fermented matrices, and (ii) genera/species detected in the monitoring of spontaneous fermentation. The first is the case of pathogens, while to the second class often belong producers of mycotoxins, ethyl carbamate, and biogenic amines. Hence, the second class is more insidious, considering that in the same species we can also find strains of protechnological interest and strains liable to produce toxic compounds.

If we focus on the inoculum enrichment managements, one other way to examine the question of microbial-related risks associated with spontaneous fermentations is to consider the positive list of microbial species admitted under the umbrella of status such as Qualified Presumption of Safety (QPS). This list has been developed, and continuously updated, by the European Food Safety Authority (EFSA) to evaluate the safety of biological agents intentionally added during food processing, with the aim of harmonizing the risk management associated with microbial food cultures in Europe [6]. Having a look at the list of microbial species and genera reported in Table 1, it is easy to observe an asymmetry in comparison with the list of QPS microbes. This variance provides us an idea of how difficult is to rely on spontaneous microbial consortia to drive food fermentations and at the same time assure food safety [20].

\section{The Need for a Transdisciplinary Assessment: Towards a "Third Way" to Conciliate Actual Trends and Risks Avoidance}

Health benefits associated with the consumption of fermented foods and beverages are often claimed $[1,2,27]$. However, this good reputation in terms of nutritional and functional quality represents one more reason to assure a risk management tailored to minimize the probability of contaminations. Consistent microbial-related safety issues deal with the rising interest of the artisanal food sector in spontaneous fermentations (including all the kinds of practices that rely on native microbial communities without the required microbiological and chemical controls). A revamp of "artisanal food microbiology" could not only reestablish the artisanal content, but also restore the scarce hygienic conditions that characterized underdeveloped food systems.

In the scientific literature, it is possible to underline existing approaches that, surpassing the dichotomy between relying on spontaneous fermentation and the use of commercial starter cultures, depict a "third way" to conjugate the interest in enhancing the artisanal attributes by means of tailor-made fermentation strategies with the need of a correct management of microbial-related risks in the final products. In this heterogeneous set of approaches, three main categories of studies can be identified. Firstly, the works that, starting from a genotypic and technological characterization of microbial diversity associated to giving food spontaneous fermentation, proposed the design of a multi-strains starter culture to be used in the associated food production in order to improve the "unique qualities" recognized as artisanal attributes $[4,6,20]$. In addition, there are numerous examples of biotechnological and analytical methodologies that allow the monitoring of the microbial-based 
contaminants associated with a given spontaneous food fermentation [28-31]. Finally, the case of studies that applied the safety standard used to assess the compliance of single microorganisms in order to evaluate the safety of the microbial diversity at the basis of inoculum enrichment management [32]. However, neither of these approaches proposed represent reference solutions for the desired renaissance in artisanal food microbiology. The reason why is probably connected i) with the general, limited education in microbiology of the key actors working in the field [33] and ii) with the poor coordination among the approaches belonging to a different disciplinary environment and among quadruple helix stakeholders [34]. Many questions remain open when dealing with different sectors, e.g., regulatory compliance, right importance in product specifications, low-cost approach to produce microbial biomass, and potentiating comprehension and approval of the consumers and of the stakeholders, even if, concerning specific aspects, some resolutions have been suggested $[14,35]$.

\section{Conclusions}

Fermented foods and beverages represent a worldwide category of edible products with a huge scientific dimension, social relevance, and economic significance. To provide a general idea of the present global interest in this field, we can remember that about one-third of food produced for human consumption worldwide is a fermented edible matrix [36]. Furthermore, the attention of prestigious international institutions, such as the World Health Organization (WHO) and Food and Agriculture Organization (FAO) of the United Nations (UN), to the importance of microbiological risks assessment [37] and of traditional fermented food and beverages [19] contributes to testify to the relevance of the discussed topic. In this opinion paper, we underline the urgency of a holistic effort of all the stakeholders involved to conciliate actual trends and risk avoidance in the management of microbial resources in artisanal fermented foods and beverages by means of a shared global regulatory/applicative framework. A major control of the microbiology related to the fermentation of artisanal foods can represent a milestone in the valorization of the biotechnological potential associated with characterized strains belonging to spontaneous fermentation. Additionally, the valorization of selected microbial resources can be crucial to improve, more generally, the global quality of artisanal fermented products by: (i) enhancing biocontrol activities [38-40], (ii) ameliorating nutrient contents [41,42], (iii) augmenting functional properties [43,44], (iv) increasing organoleptic features [45,46], and (v) helping to cope with global issues such as the negative influences of climate changes [47]. Moreover, by reducing the negative risks and improving beneficial effects connected to artisanal fermented products, we might add a further piece to the puzzle of pursuing a One Health approach in the field of fermented foods [48]. Certainly, the recent advances in genomes and metagenomic analysis, allowing innovative safety assessment and fermentative monitoring [22,23,49-52], could provide new approaches to cope with the needs of artisanal food microbiology.

Author Contributions: Investigation, M.F., P.R. and V.C.; conceptualization, M.F., P.R. and V.C.; literature search, M.F., P.R. and V.C.; writing—original draft preparation, M.F., P.R. and V.C.; writing—review and editing, M.F., P.R. and V.C. All authors have read and agreed to the published version of the manuscript.

Funding: Pasquale Russo is the beneficiary of a grant by MIUR in the framework of 'AIM: Attraction and International Mobility' (PON R\&I 2014-2020) (practice code D74I18000190001).

Acknowledgments: We would like to thank the two anonymous reviewers for their suggestions and comments. The authors acknowledge Francesco De Marzo of the Institute of Sciences of Food Production-CNR for the skilled technical support provided during the realization of this work.

Conflicts of Interest: The authors declare no conflict of interest.

\section{References}

1. Marco, M.L.; Heeney, D.; Binda, S.; Cifelli, C.J.; Cotter, P.D.; Foligné, B.; Gänzle, M.; Kort, R.; Pasin, G.; Pihlanto, A.; et al. Health benefits of fermented foods: Microbiota and beyond. Curr. Opin. Biotechnol. 2017, 44, 94-102. [CrossRef] 
2. Dimidi, E.; Cox, S.R.; Rossi, M.; Whelan, K. Fermented Foods: Definitions and Characteristics, Impact on the Gut Microbiota and Effects on Gastrointestinal Health and Disease. Nutrients 2019, 11, 1806. [CrossRef] [PubMed]

3. Tamang, J.P.; Watanabe, K.; Holzapfel, W.H. Review: Diversity of Microorganisms in Global Fermented Foods and Beverages. Front. Microbiol. 2016, 7, 377. [CrossRef] [PubMed]

4. Capozzi, V.; Spano, G. Food microbial biodiversity and "microbes of protected origin". Front. Microbiol. 2011, 2, 237. [CrossRef] [PubMed]

5. Brandt, M.J. Starter cultures for cereal based foods. Food Microbiol. 2014, 37, 41-43. [CrossRef]

6. Russo, P.; Spano, G.; Capozzi, V. Safety evaluation of starter cultures. In Starter Cultures in Food Production; John Wiley \& Sons, Ltd.: Hoboken, NJ, USA, 2017; pp. 101-128. ISBN 978-1-118-93379-4.

7. Leroy, F.; De Vuyst, L. Lactic acid bacteria as functional starter cultures for the food fermentation industry. Trends Food Sci. Technol. 2004, 15, 67-78. [CrossRef]

8. Hansen, E.B. STARTER CULTURES | Uses in the Food Industry. In Encyclopedia of Food Microbiology, 2nd ed.; Batt, C.A., Tortorello, M.L., Eds.; Academic Press: Oxford, UK, 2014; pp. 529-534. ISBN 978-0-12-384733-1.

9. Wuyts, S.; Beeck, W.V.; Oerlemans, E.F.M.; Wittouck, S.; Claes, I.J.J.; Boeck, I.D.; Weckx, S.; Lievens, B.; Vuyst, L.D.; Lebeer, S. Carrot Juice Fermentations as Man-Made Microbial Ecosystems Dominated by Lactic Acid Bacteria. Appl. Environ. Microbiol. 2018, 84, e00134-18. [CrossRef]

10. Farnworth, E.R.T. Handbook of Fermented Functional Foods; CRC Press: Boca Raton, FL, USA, 2003; ISBN 978-0-429-21454-7.

11. Petruzzi, L.; Capozzi, V.; Berbegal, C.; Corbo, M.R.; Bevilacqua, A.; Spano, G.; Sinigaglia, M. Microbial Resources and Enological Significance: Opportunities and Benefits. Front. Microbiol. 2017, 8, 995. [CrossRef]

12. Greppi, A.; Rantsiou, K.; Padonou, W.; Hounhouigan, J.; Jespersen, L.; Jakobsen, M.; Cocolin, L. Determination of yeast diversity in ogi, mawè, gowé and tchoukoutou by using culture-dependent and -independent methods. Int. J. Food Microbiol. 2013, 165, 84-88. [CrossRef]

13. Meulen, V.D.; S, H. A normative definition method for origin food products. Anthropol. Food 2007, S2. [CrossRef]

14. Capozzi, V.; Russo, P.; Spano, G. Microbial information regimen in EU geographical indications. World Pat. Inf. 2012, 34, 229-231. [CrossRef]

15. Cirne, C.T.; Tunick, M.H.; Trout, R.E. The chemical and attitudinal differences between commercial and artisanal products. Npj Sci. Food 2019, 3, 1-4. [CrossRef] [PubMed]

16. Counihan, C.; Esterik, P.V. Food and Culture: A Reader; Routledge: New York, NY, USA, 2012; ISBN 978-0-203-07975-1.

17. Johnson, A.J. Artisanal food microbiology. Nat. Microbiol. 2016, 1, 1-3. [CrossRef] [PubMed]

18. Cocolin, L.; Gobbetti, M.; Neviani, E.; Daffonchio, D. Ensuring safety in artisanal food microbiology. Nat. Microbiol. 2016, 1, 1. [CrossRef]

19. Marshall, E.; Mejía-Loríio, D.J. (Eds.) Traditional Fermented Food and Beverages for Improved Livelihoods; FAO Diversification booklet; Rural Infrastructure and Agro-Industries Division, Food and Agriculture Organization of the United Nations: Rome, Italy, 2011; ISBN 978-92-5-107074-1.

20. Capozzi, V.; Fragasso, M.; Romaniello, R.; Berbegal, C.; Russo, P.; Spano, G. Spontaneous Food Fermentations and Potential Risks for Human Health. Fermentation 2017, 3, 49. [CrossRef]

21. Sivamaruthi, B.S.; Kesika, P.; Chaiyasut, C. Toxins in Fermented Foods: Prevalence and Preventions-A Mini Review. Toxins 2019, 11, 4. [CrossRef]

22. Kumar, J.; Sharma, N.; Kaushal, G.; Samurailatpam, S.; Sahoo, D.; Rai, A.K.; Singh, S.P. Metagenomic Insights Into the Taxonomic and Functional Features of Kinema, a Traditional Fermented Soybean Product of Sikkim Himalaya. Front. Microbiol. 2019, 10, 1744. [CrossRef]

23. Walsh, A.M.; Crispie, F.; Daari, K.; O’Sullivan, O.; Martin, J.C.; Arthur, C.T.; Claesson, M.J.; Scott, K.P.; Cotter, P.D. Strain-Level Metagenomic Analysis of the Fermented Dairy Beverage Nunu Highlights Potential Food Safety Risks. Appl. Environ. Microbiol. 2017, 83, e01144-17. [CrossRef]

24. Adekoya, I.; Njobeh, P.; Obadina, A.; Chilaka, C.; Okoth, S.; De Boevre, M.; De Saeger, S. Awareness and Prevalence of Mycotoxin Contamination in Selected Nigerian Fermented Foods. Toxins 2017, 9, 363. [CrossRef]

25. Nout, M.J.R. Fermented foods and food safety. Food Res. Int. 1994, 27, 291-298. [CrossRef] 
26. Russo, P.; Fragasso, M.; Berbegal, C.; Grieco, F.; Spano, G.; Capozzi, V. Chapter 2:Microorganisms Able to Produce Biogenic Amines and Factors Affecting Their Activity. In Biogenic Amines in Food; RSC Publishing: Cambridge, UK, 2019; pp. 18-40.

27. Melini, F.; Melini, V.; Luziatelli, F.; Ficca, A.G.; Ruzzi, M. Health-Promoting Components in Fermented Foods: An Up-to-Date Systematic Review. Nutrients 2019, 11, 1189. [CrossRef] [PubMed]

28. Cimaglia, F.; Tristezza, M.; Saccomanno, A.; Rampino, P.; Perrotta, C.; Capozzi, V.; Spano, G.; Chiesa, M.; Mita, G.; Grieco, F. An innovative oligonucleotide microarray to detect spoilage microorganisms in wine. Food Control. 2018, 87, 169-179. [CrossRef]

29. Wang, Y.; Salazar, J.K. Culture-Independent Rapid Detection Methods for Bacterial Pathogens and Toxins in Food Matrices. Compr. Rev. Food Sci. Food Saf. 2016, 15, 183-205. [CrossRef]

30. Valderrama, W.B.; Dudley, E.G.; Doores, S.; Cutter, C.N. Commercially Available Rapid Methods for Detection of Selected Food-borne Pathogens. Crit. Rev. Food Sci. Nutr. 2016, 56, 1519-1531. [CrossRef]

31. Zhao, Y.; Wang, H.; Zhang, P.; Sun, C.; Wang, X.; Wang, X.; Yang, R.; Wang, C.; Zhou, L. Rapid multiplex detection of 10 foodborne pathogens with an up-converting phosphor technology-based 10-channel lateral flow assay. Sci. Rep. 2016, 6, 1-8. [CrossRef]

32. Rossetti, L.; Carminati, D.; Zago, M.; Giraffa, G. A Qualified Presumption of Safety approach for the safety assessment of Grana Padano whey starters. Int. J. Food Microbiol. 2009, 130, 70-73. [CrossRef]

33. Capozzi, V.; Spano, G.; Fiocco, D. Transdisciplinarity and Microbiology Education. J. Microbiol. Biol. Educ. JMBE 2012, 13, 70-73. [CrossRef]

34. Carayannis, E.G.; Campbell, D.F.J. Mode 3 Knowledge Production in Quadruple Helix Innovation Systems. In Mode 3 Knowledge Production in Quadruple Helix Innovation Systems: 21st-Century Democracy, Innovation, and Entrepreneurship for Development; Carayannis, E.G., Campbell, D.F.J., Eds.; SpringerBriefs in Business; Springer: New York, NY, USA, 2012; pp. 1-63. ISBN 978-1-4614-2062-0.

35. Maqueda, M.; Pérez-Nevado, F.; Regodón, J.A.; Zamora, E.; Álvarez, M.L.; Rebollo, J.E.; Ramírez, M. A low-cost procedure for production of fresh autochthonous wine yeast. J. Ind. Microbiol. Biotechnol. 2011, 38, 459-469. [CrossRef]

36. Vogel, R.F.; Hammes, W.P.; Habermeyer, M.; Engel, K.-H.; Knorr, D.; Eisenbrand, G. Microbial food cultures-Opinion of the Senate Commission on Food Safety (SKLM) of the German Research Foundation (DFG). Mol. Nutr. Food Res. 2011, 55, 654-662. [CrossRef]

37. World Health Organization (WHO) Assessing Microbial Risks. Available online: https://www.who.int/ activities/assessing-microbial-risks-in-food (accessed on 16 February 2020).

38. Berbegal, C.; Garofalo, C.; Russo, P.; Pati, S.; Capozzi, V.; Spano, G. Use of Autochthonous Yeasts and Bacteria in Order to Control Brettanomyces bruxellensis in Wine. Fermentation 2017, 3, 65. [CrossRef]

39. Arena, M.P.; Russo, P.; Spano, G.; Capozzi, V. Exploration of the Microbial Biodiversity Associated with North Apulian Sourdoughs and the Effect of the Increasing Number of Inoculated Lactic Acid Bacteria Strains on the Biocontrol against Fungal Spoilage. Fermentation 2019, 5, 97. [CrossRef]

40. Russo, P.; Fares, C.; Longo, A.; Spano, G.; Capozzi, V. Lactobacillus plantarum with Broad Antifungal Activity as a Protective Starter Culture for Bread Production. Foods 2017, 6, 110. [CrossRef] [PubMed]

41. Russo, P.; Capozzi, V.; Arena, M.P.; Spadaccino, G.; Dueñas, M.T.; López, P.; Fiocco, D.; Spano, G. Riboflavin-overproducing strains of Lactobacillus fermentum for riboflavin-enriched bread. Appl. Microbiol. Biotechnol. 2014, 98, 3691-3700. [CrossRef]

42. Capozzi, V.; Russo, P.; Dueñas, M.T.; López, P.; Spano, G. Lactic acid bacteria producing B-group vitamins: A great potential for functional cereals products. Appl. Microbiol. Biotechnol. 2012, 96, 1383-1394. [CrossRef] [PubMed]

43. Missaoui, J.; Saidane, D.; Mzoughi, R.; Minervini, F. Fermented Seeds ("Zgougou") from Aleppo Pine as a Novel Source of Potentially Probiotic Lactic Acid Bacteria. Microorganisms 2019, 7, 709. [CrossRef] [PubMed]

44. Pino, A.; Russo, N.; Van Hoorde, K.; De Angelis, M.; Sferrazzo, G.; Randazzo, C.L.; Caggia, C. Piacentinu Ennese PDO Cheese as Reservoir of Promising Probiotic Bacteria. Microorganisms 2019, 7, 254. [CrossRef]

45. Gerardi, C.; Tristezza, M.; Giordano, L.; Rampino, P.; Perrotta, C.; Baruzzi, F.; Capozzi, V.; Mita, G.; Grieco, F. Exploitation of Prunus mahaleb fruit by fermentation with selected strains of Lactobacillus plantarum and Saccharomyces cerevisiae. Food Microbiol. 2019, 84, 103262. [CrossRef] 
46. Capozzi, V.; Makhoul, S.; Aprea, E.; Romano, A.; Cappellin, L.; Sanchez Jimena, A.; Spano, G.; Gasperi, F.; Scampicchio, M.; Biasioli, F. PTR-MS Characterization of VOCs Associated with Commercial Aromatic Bakery Yeasts of Wine and Beer Origin. Molecules 2016, 21, 483. [CrossRef]

47. Berbegal, C.; Fragasso, M.; Russo, P.; Bimbo, F.; Grieco, F.; Spano, G.; Capozzi, V. Climate Changes and Food Quality: The Potential of Microbial Activities as Mitigating Strategies in the Wine Sector. Fermentation 2019, 5, 85. [CrossRef]

48. Bell, V.; Ferrão, J.; Pimentel, L.; Pintado, M.; Fernandes, T. One Health, Fermented Foods, and Gut Microbiota. Foods 2018, 7, 195. [CrossRef]

49. Berbegal, C.; Borruso, L.; Fragasso, M.; Tufariello, M.; Russo, P.; Brusetti, L.; Spano, G.; Capozzi, V. A Metagenomic-Based Approach for the Characterization of Bacterial Diversity Associated with Spontaneous Malolactic Fermentations in Wine. Int. J. Mol. Sci. 2019, 20, 3980. [CrossRef] [PubMed]

50. Orrù, L.; Salvetti, E.; Cattivelli, L.; Lamontanara, A.; Michelotti, V.; Capozzi, V.; Spano, G.; Keller, D.; Cash, H.; Martina, A.; et al. Draft Genome Sequence of Bacillus coagulans GBI-30, 6086, a Widely Used Spore-Forming Probiotic Strain. Genome Announc. 2014, 2, e01080-14.

51. Salvetti, E.; Orrù, L.; Capozzi, V.; Martina, A.; Lamontanara, A.; Keller, D.; Cash, H.; Felis, G.E.; Cattivelli, L.; Torriani, S.; et al. Integrate genome-based assessment of safety for probiotic strains: Bacillus coagulans GBI-30, 6086 as a case study. Appl. Microbiol. Biotechnol. 2016, 100, 4595-4605. [CrossRef] [PubMed]

52. Alkema, W.; Boekhorst, J.; Wels, M.; van Hijum, S.A.F.T. Microbial bioinformatics for food safety and production. Brief. Bioinform. 2016, 17, 283-292. [CrossRef] [PubMed]

(C) 2020 by the authors. Licensee MDPI, Basel, Switzerland. This article is an open access article distributed under the terms and conditions of the Creative Commons Attribution (CC BY) license (http://creativecommons.org/licenses/by/4.0/). 